\title{
CONTRIBUTION OF GARDEN ARCHITECTURE TO THE REGIONAL DEVELOPMENT
}

\author{
Viera PETRÁŠOVÁ*, Janka BERESECKÁ, Jana JARÁBKOVÁ, Katarína MELICHOVÁ, Maroš VALACH \\ Slovak University of Agriculture in Nitra, Slovak Republic
}

Creative garden architecture currently affects regional development in two ways. Firstly, it results in landscape architecture outputs, horticulture arrangements, and garden projects. Secondly, it constitutes an environment for the development of certain business activities, namely tourism and horticulture. Garden architecture is able to secure the development of land-based economy, replacing the decreased production of agricultural commodities, and thus contributing to regional development. Garden architecture businesses in the Nitra region are currently limited by the lack of their potential clients' financial resources as well as the barriers to entrepreneurship created in the Slovak Republic. The number of the businesses in the region enables them to develop mutual cooperation without the need for strong competition. On the contrary, it encourages the diversification of business activities, various levels of their specialization and potential development of partnerships in a region.

Keywords: garden architecture, barriers to entrepreneurship, creativity

The term 'creativity', the central element in the process of creative economy formation cannot be clearly defined due to its multidimensional character. The key aspects of creativity can be identified by several approaches, as scientific literature puts it. However, the qualities such as originality, usefulness and innovativeness are emphasized in general. The multidimensional understanding of creativity is also supported by Florida (2002) and Markussena et al. (2008), who identifies the following three types of creativity in his paper entitled Entrepreneurship, Creativity, and Regional Development:

1. technological (innovations),

2. economic (entrepreneurship, usefulness),

3. artistic and cultural (originality).

These three types of creativity are interdependent. In order to generate economic activity in a region, conditions stimulating innovations, arts and culture have to be created. In case the economic effects of creativity on regional policy and economy are applied, other definitions of creativity can be used, too. For example, the ARC Centre for Excellence in Creative Industries \& Innovation developed the Creative Trident approach to evaluate the dynamics of creative labour force (Florida, 2002):

- creative specialists (employed at creative positions in creative industries),

- support staff (employed at non-creative positions in creative industries),

- embedded workers (employed at creative positions in industries which do not produce creative products).

The objective of the paper is to present the garden architects' contribution on regional level in the Nitra region. It is based on the goals and parts of objectives of the scientific research project KRENAR. The KRENAR (Creative economy National economic and regional conditions and stimuli) project utilizes multidimensional and interdisciplinary approach, with a wide participation of experts in various social and humanity sciences. Its goals are as follows:
- to analyse the conditions and factors influencing regional and municipal development during the last 10 years and to identify the local position of the selected creative industries,

- to analyse the changes which formed the new political, economic and administrative situation, and their social and spatial effects, to identify the barriers to and opportunities for entrepreneurship in the selected industries,

- to explore various personal incentives to entrepreneurship in a creative industry (to analyse the horizontal - social and spatial as well as the vertical - social and economic differentiation),

- to analyse in particular the positive and negative availabilities of the Slovak Republic towards the selected industries, and their impact on the development of businesses and, consequently, regions.

The paper is focused on the situation in the Nitra region, with respect to the position of garden architecture in current legislation and economic conditions, based on the analysis of the business structure and the results of the research carried out with respondents running business in the sector. The analysis indicated that the stakeholders assigned particular importance to social land use functions, such as jobs, as well as environmental land use functions and ecosystem processes (König et al., 2014).

\section{Material and methods}

The material for the analysis of the current state of the issue and the sector was processed based on secondary sources, while the research data was obtained from primary sources. 1. Primary sources consist of the data acquired from the outcomes of a structured interview conducted with selected agents from the field of garden architecture, active in the Nitra region.

2. Secondary data was obtained from the following sources: 


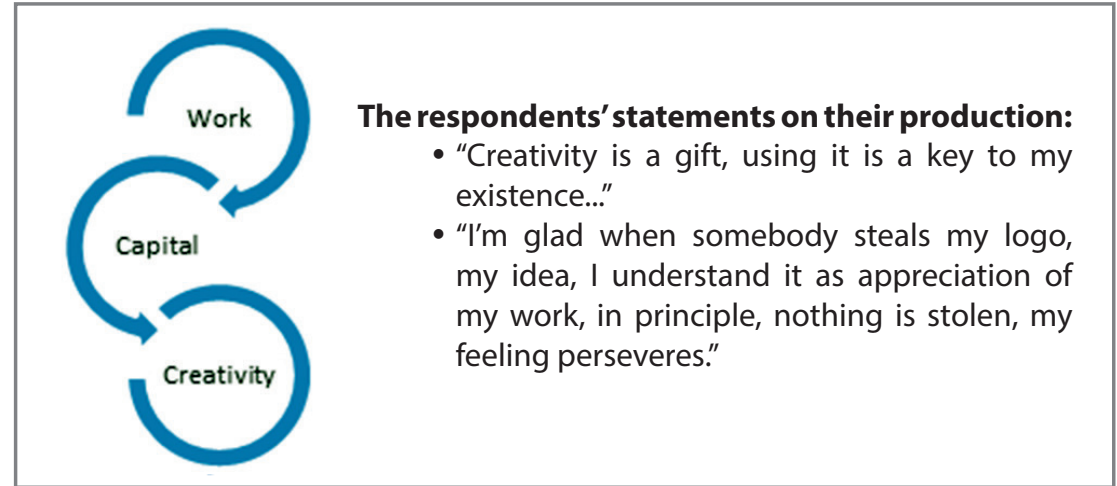

Figure 1 Synthesis of the inputs to creative garden architecture

- books of domestic as well as foreign authors,

- Internet sources focused on specialized activities leading to creative industries,

- public administration materials concerning cultural and creative economy,

- expert papers on creativity,

- legislation of the Slovak Republic and the European Union.

The methods used to carry out research:

- The synthesis of the theoretical information and available analyses.

- The questionnaire method a structured interview.

The objective of the questionnaire was to obtain background data for the analysis of the current situation in the creative economy support on various levels of enterprises in the regional policy, and to acquire a picture of the situation as observed by the agents. The target group consisted of 20 representatives of garden architecture from the Nitra region.

The questionnaire was structured and divided into the following questions: - basic data, description of history and current position of an entrepreneur,

- place where an entrepreneur works, space for his/her creative production,

- economy: position of an enterprise in the regional economy, dependence on external sources...,

- policy: barriers and opportunities of policies on different levels of the vertical state administration,

- localization and cooperation: horizontal position of an enterprise and its localization within the Nitra region.

\section{Results and discussion}

Defining the industry

Horticulture is a technical discipline, but garden architecture is an artistic creation. Landscape architecture products are based on linking the environment (material) to philosophy. In other words, it brings ideas, sense and perceptions into any environment. Landscape architects use the outcomes of scientific research and skills of landscape engineers to avoid making fundamental mistakes in their products. It may be stated that in general, a garden architect needs to link labour, capital, and creativity (Figure 1). The respondents expressed themselves in a similar way.

\section{Local position and cooperation in the Nitra region}

According to the statistical classification of economic activities SK NACE Rev. 2 , the researched creative industry garden architecture belong to the section M - PROFESSIONAL, SCIENTIFIC AND TECHNICAL ACTIVITIES, subsector 71.11.0 Architectural activities, and section N - ADMINISTRATIVE AND SUPPORT SERVICE ACTIVITIES, subsector 81.30.0 Landscape service activities. However, in the section $\mathrm{N}$ there is a great number of enterprises dealing

Table 1 Structure of the industry in Nitra region with regard to the type of legal form of business entity (2013)

\begin{tabular}{|l||c|c|c|c|c|c|}
\hline Type of business entity & \multicolumn{1}{|c|}{ Architectural activities } & \multicolumn{2}{|c|}{ Landscape service activities } & \multicolumn{2}{c|}{ Total } \\
\hline \hline $\begin{array}{l}\text { Entrepreneur-physical person-not entered in Business } \\
\text { Register }\end{array}$ & 32 & $15.92 \%$ & 81 & $54.73 \%$ & 113 & $32.38 \%$ \\
\hline Private farmer not entered in Business Register & 0 & $0.00 \%$ & 1 & $0.68 \%$ & 1 & $0.29 \%$ \\
\hline $\begin{array}{l}\text { Freelance occupation-physical person active on } \\
\text { the basis of other legislation than Small Business Act }\end{array}$ & 67 & $33.33 \%$ & 0 & $0.00 \%$ & 67 & $19.20 \%$ \\
\hline $\begin{array}{l}\text { Entrepreneur-physical person-not entered in Business } \\
\text { Register, also active as Private Farmer }\end{array}$ & 0 & $0.00 \%$ & 4 & $2.70 \%$ & 4 & $1.15 \%$ \\
\hline $\begin{array}{l}\text { Entrepreneur-physical person-not entered in Business } \\
\text { Register-also active in Freelance Occupation }\end{array}$ & 41 & $20.40 \%$ & 2 & $1.35 \%$ & 43 & $12.32 \%$ \\
\hline Public commercial company & 1 & $0.50 \%$ & 0 & $0.00 \%$ & 1 & $0.29 \%$ \\
\hline Limited liability company & 56 & $27.86 \%$ & 58 & $39.19 \%$ & 114 & $32.66 \%$ \\
\hline Joint stock company & 1 & $0.50 \%$ & 0 & $0.00 \%$ & 1 & $0.29 \%$ \\
\hline Cooperative & 0 & $0.00 \%$ & 1 & $0.68 \%$ & 1 & $0.29 \%$ \\
\hline Organization based on state contributions & 1 & $0.50 \%$ & 1 & $0.68 \%$ & 2 & $0.57 \%$ \\
\hline Foreign person, legal unit & 2 & $1.00 \%$ & 0 & $0.00 \%$ & 2 & $0.57 \%$ \\
\hline Total & 201 & $100.00 \%$ & 148 & $100.00 \%$ & 349 & $100.00 \%$ \\
\hline
\end{tabular}

Source: SO SR 


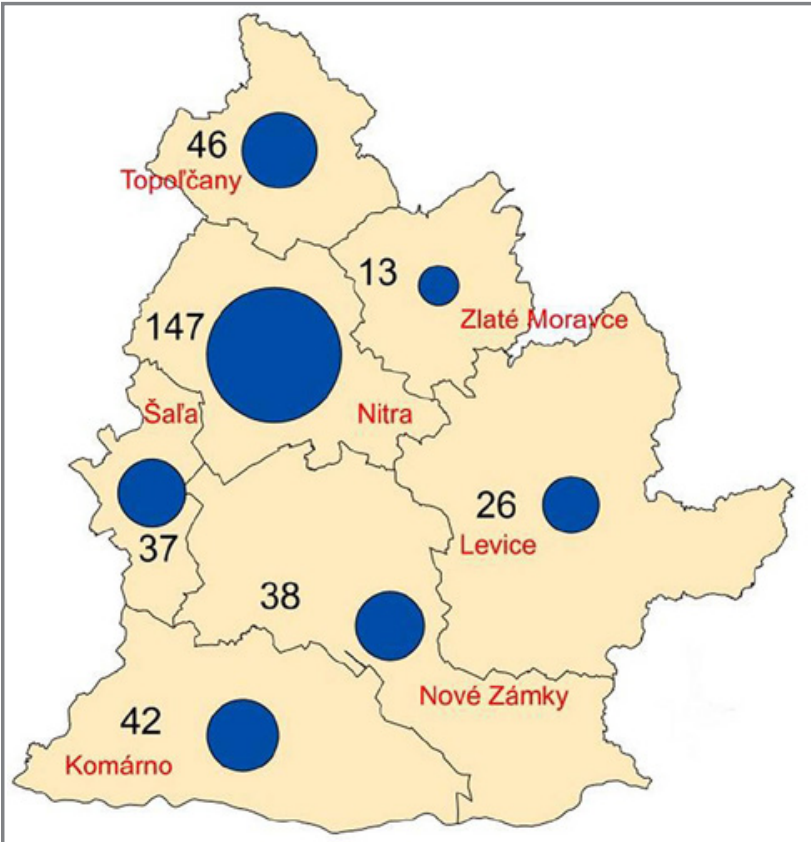

Figure 2 Number of enterprises in the creative industry garden architecture in the Nitra region districts in 2013 Source: own processing based on the SO SR data

with landscape management only, with no creative activities (Milotová, 2012).

According to the Statistical Office of the Slovak Republic (SO SR) data, there were 349 business subjects belonging to the industry in the Nitra region in 2013 (Table 1). There are 201 subjects in the section M and 148 ones in the section $\mathrm{N}$, most of them located in the Nitra district, which is documented in Fig. 2. In terms of the legal form, limited liability companies prevail with $32.66 \%$.

The greatest number of the enterprises is located directly in Nitra. The enterprises presented in Table 1 are focused not only on garden architecture, but their production and support services form an environment which is favourable for creative cooperation in the field.

\section{Local position and structure of the questioned garden architects}

The results of the creative industry garden architecture analysis in the Nitra region are based on 20 interviews performed in the districts of Nitra, Nové Zámky, Zlaté Moravce, and Topol'čany. In terms of the legal form, $70 \%$ of the respondents belong to entrepreneurs - physical persons and persons active on the basis of Small Business Act. Limited liability companies represent $30 \%$ of the respondents (Table 2). As much as $65 \%$ of the respondents are localized in the Nitra district, which is documented in Figure 3.

The number of the respondents active in the field in Nitra is dependent on the number of entrepreneurs active in the

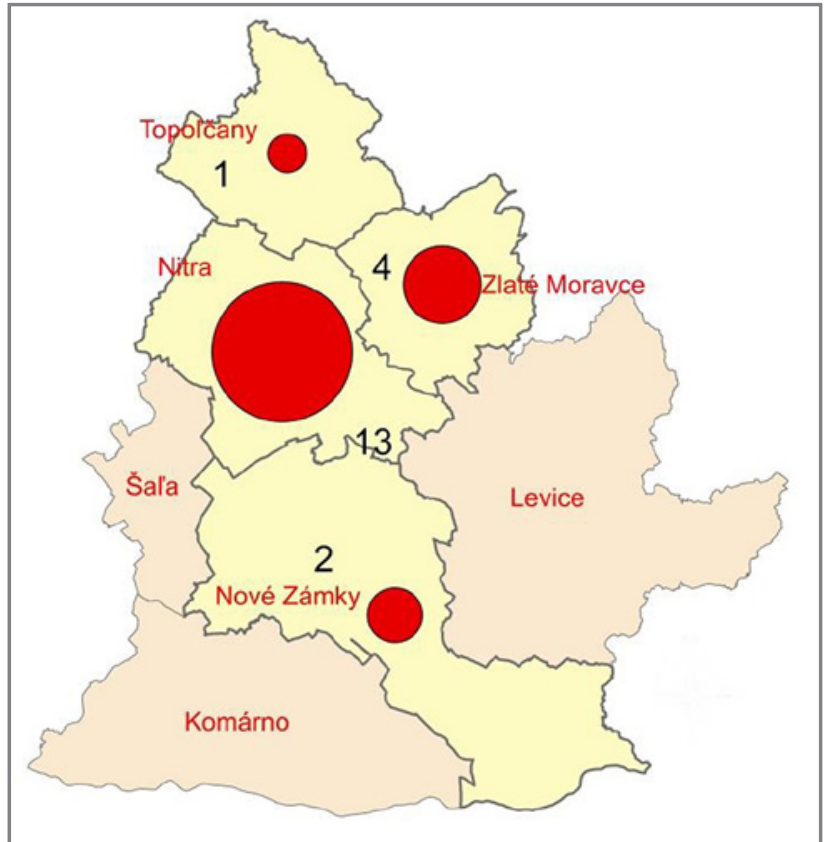

Figure 3 Number of respondents in the Nitra region districts Source: own processing

whole Nitra region. Most of them started running business after 2000 (75\%), only 5 respondents started earlier.

In terms of employees, $45.0 \%$ of the respondents do not have any, $5.0 \%$ have 1-5 employees, $20.0 \%$ employ 5-20 persons, and none more than 20 employees (Table 3). A significant share of the employees in the questioned creative enterprises work on a part-time basis. Such cases occur among the entrepreneurs - physical persons and entrepreneurs active on the basis of Small Business Act in particular.

Table 3 Structure of respondents by number of employees

\begin{tabular}{|l||c|}
\hline Size category & Share in \% \\
\hline \hline $\mathbf{0}$ & 45.0 \\
\hline $\mathbf{1 - 5}$ & 35.0 \\
\hline $\mathbf{5 - 2 0}$ & 20.0 \\
\hline over $\mathbf{2 0}$ & 0.0 \\
\hline \multicolumn{2}{|c||}{ Source: own processing } \\
\hline
\end{tabular}

The educational structure of the respondents confirmed the opinion that the Slovak University of Agriculture in Nitra (SUA) has played an important role in the training of professionals for the field of garden architecture. Out of the questioned enterprises, as much as $76 \%$ of their owners achieved the master degree at the University, $41 \%$ of them at the Faculty of Horticulture and Landscape Engineering

Table 2 Structure of respondents by legal form

\begin{tabular}{|l||c|}
\hline Legal form & Share on total in \% \\
\hline \hline Entrepreneurs - physical persons and persons active on the basis of Small Business Act & 70.0 \\
\hline Legal persons - Limited liability companies & 30.0 \\
\hline
\end{tabular}




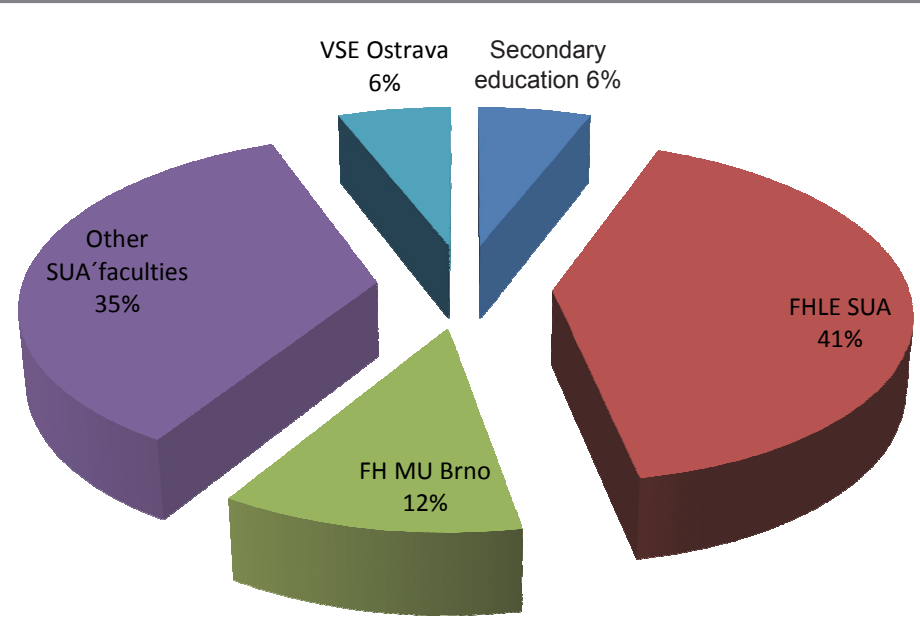

Figure 4 Education of the questioned garden architects Source: own processing

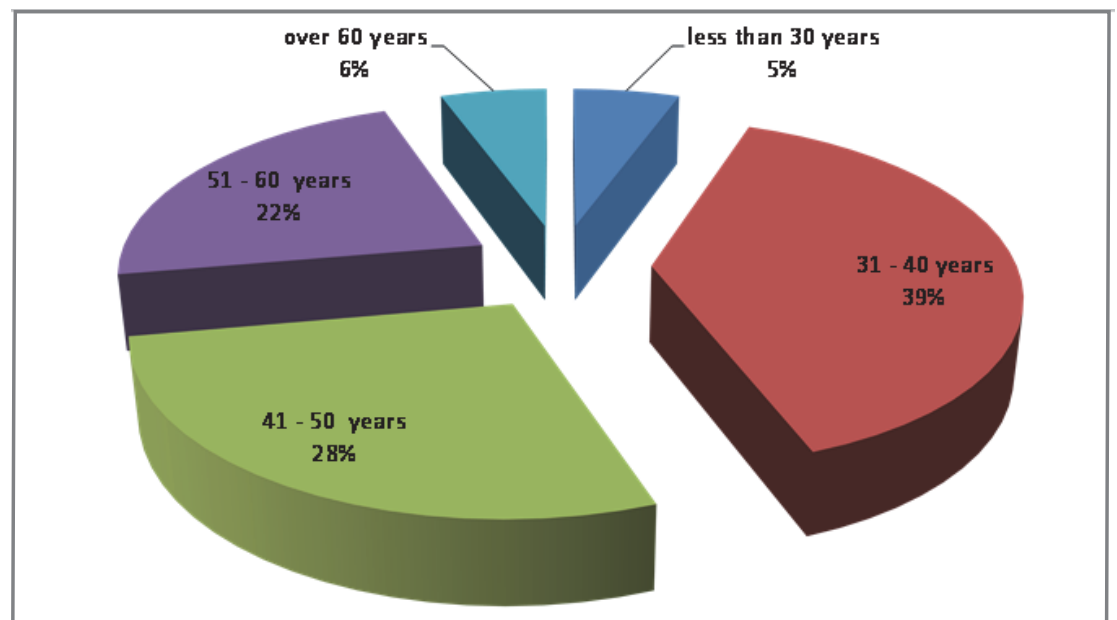

Figure 5 Age structure of the questioned garden architects Source: own processing

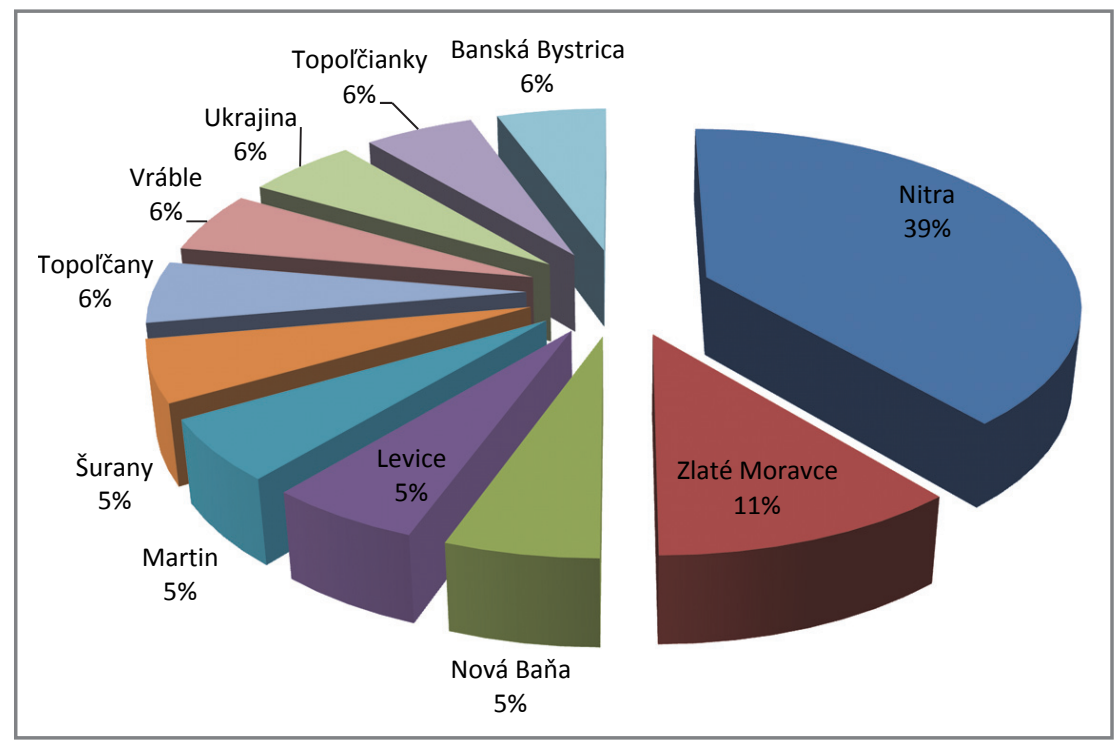

Figure 6 Place of birth of the questioned garden architects Source: own processing

(FHLE). Further $12 \%$ of the respondents are graduates of the Faculty of Horticulture, Mendel University (FH MU), Brno. It can be stated that most of the owners are qualified professionals with university education in the field.

In terms of age structure, the entrepreneurs in productive age prevail. The age group of 31-40 years reached the highest representation among the respondents - $39 \%$. Men and women were represented equally.

Most of the respondents (83\%) come from the Nitra region and live there, too. As for the place of birth, $39 \%$ of the respondents named Nitra, $11 \%$ Zlaté Moravce, and others Vráble, Topol'čany, Topol'čianky, Šurany, Levice, Nová Baňa. The place of birth is mostly identical to the place of the respondents' business activities (75\%).

The reason why the entrepreneurs decided to live in given places is their family background in particular, which is crucial mainly for young families with children. Being close to a family enables an entrepreneur to allocate enough time for business. Personal connections in a place of birth facilitate starting a business (many garden architecture businesses started with projects and their materialisation for their friends and relatives), and enable its faster enforcement in a well-known local market. The decisions concerning places of living and business were also affected by ownership of real estate in a municipality and an opportunity of employment, also in a case of self-employment.

\section{Specific features of the enterprises \\ active in the fields of garden and landscape architecture (the Nitra region example)}

The sample of the enterprises from the field of garden and landscape architecture presents 20 selected business subjects localized in the Nitra region. The oldest questioned enterprise was founded in 1995, the youngest one in 2012. As for the legal form, physical persons operating on the basis of Small Business Act prevail with $70 \%$, the rest is comprised of legal persons in only one legal form - limited liability company. The family character of the questioned enterprises is one of the specific features. The family enterprises are managed by married 
couples as partners or by one of a couple with divided managerial competencies. The family enterprises also often employ further relatives or people close to a family with good references in the environment.

In terms of the number of employees, garden and landscape architecture enterprises represent small businesses with 4-12 employees (45 \%) and microbusinesses with 3 and less employees (55 \%). Within the micro-businesses there are also physical persons who do not create any other jobs or employ people on agreements for performance of work as auxiliaries or seasonal staff. The whole sector is characteristic with low share of new permanent positions. If there are some, it is mainly in projection activities where relevant qualification is necessary. Otherwise, there are only seasonal jobs with no higher qualification required, serving as sources of additional income, while such workers often have other jobs which are considered superior. The seasonal jobs are often performed by high school and college students who do it in their free time as part-time jobs.

Theenterprises arelocated mainly in urban municipalities: Nitra, Zlaté Moravce, Nové Zámky, Topol'čany, and Vráble, but a part of them is also localized in rural municipalities: Topol'čianky, Žitavce, Svätoplukovo, Tekovské Nemce, and Nevidzany. The localization was affected by family reasons, personal bonds and contacts which were helpful in the beginnings (knowledge of a local market, references when getting first contracts), and suitable conditions for business (social and technical infrastructure). There are also specific reasons for localization in rural areas: ownership of real estate (a family house, a garden, land) or localization of warehouses.

Economic activities of the enterprises are focused mainly on services in the field of horticulture, especially projecting the ornamental gardens, materialisation of the projects and further maintenance of the gardens, sale of products for gardening, small construction works. The services are designed for owners of family houses, individual recreational objects, and business subjects. Besides the above mentioned activities, some enterprises also perform further doings: projecting the orchard arrangements, arrangements of public and private greenery, greenery passports and inventory taking, public space projects and maintenance, maintenance of local roads, wholesale and retail of garden machinery and products of vegetable origin, sale and installation of irrigation systems, consulting services, exterior and interior decoration services.

From the perspective of supplier-customer relationships, the enterprises from the field of garden and landscape architecture cooperate with quite a homogenous group of suppliers who provide them with material and carry out necessary projection and realisation activities. In the projection activities, the enterprises cooperate mainly with other projection enterprises, authorised architects and surveyor companies. In the project materialisation activities, they cooperate with stone quarrying companies, transport companies, earthmoving companies, small craftsmen, artists, planting companies, plant growing and trading companies, garden machinery trading companies, and wholesale warehouses. One third of the enterprises acts in a local market and cooperates with suppliers and customers from adjacent municipalities. The rest of the enterprises also operate beyond the Nitra region borders, cooperating with suppliers and customers mainly from the Bratislava and Trnava regions. Foreign cooperation is exceptional - there are suppliers from Austria and Hungary and customers from the Czech Republic, the Netherlands, Belgium and Poland (garden machinery, vegetable intermediates).

Knowledge of the environment and personal contacts are considered the most important attributes of a municipality in terms of one's private life. According to the localization of places of living and business (urban or rural municipality), attributes such as 'comfort of rural environment', 'nondevastated environment', inspiring surroundings, nature, good accessibility, settlements with civil infrastructure in vicinity. For private life in urban settlements, attributes such as civic amenities and possible cultural experiences are of importance. Quality of rural and urban settlements for private life was assessed similarly by the respondents; the ones living in rural settlements were a little more satisfied, with values ranging from 6 to 8 (average to above average quality), while the respondents living in urban settlements assigned the values of 5-8. Possibilities to communicate with people of similar values and interests, aesthetic values of settlements, and the inspiring character of the local nature and parks are important for private life and interests of the respondents. As much as two thirds of the respondents find the tolerance of the neighbourhood towards their production important. From the stated attributes, the environment (nature, parks), aesthetic value of a settlement and its civic amenities are the most important.

The most important local factors are: available suppliers, current favourable local market dynamics, sufficient size of a local market, accessibility of further markets (the Bratislava region in particular). The respondents also put emphasis on the favourable structure of the business sector they cooperate with, and namely:

Suppliers:

- cooperating sectors - construction companies, horticulture businesses, material transport companies, garden machinery, vegetable intermediates...

- localization of suppliers - favourable in the Nitra region, only 3 businessmen cooperate with enterprises from beyond the region, 2 businessmen cooperate with foreign-based companies.

Customers - sufficient size of the local market (contracts with individuals, companies as well as municipalities), available financial sources of customers, accessibility of further markets, dynamics of the local market development, size of the local market (Figure 7).

It is interesting that the respondents do not name the opportunities to receive public support, to present themselves or to take part in significant events (expositions at the Agrokomplex Nitra, conferences organized by the Faculty of Horticulture and Landscape Engineering, expert activities of architects' organizations, etc.) as the important ones; they are also not interested in further education, though they state they do not have enough qualified employers for the jobs in their enterprises (Figure 7). 


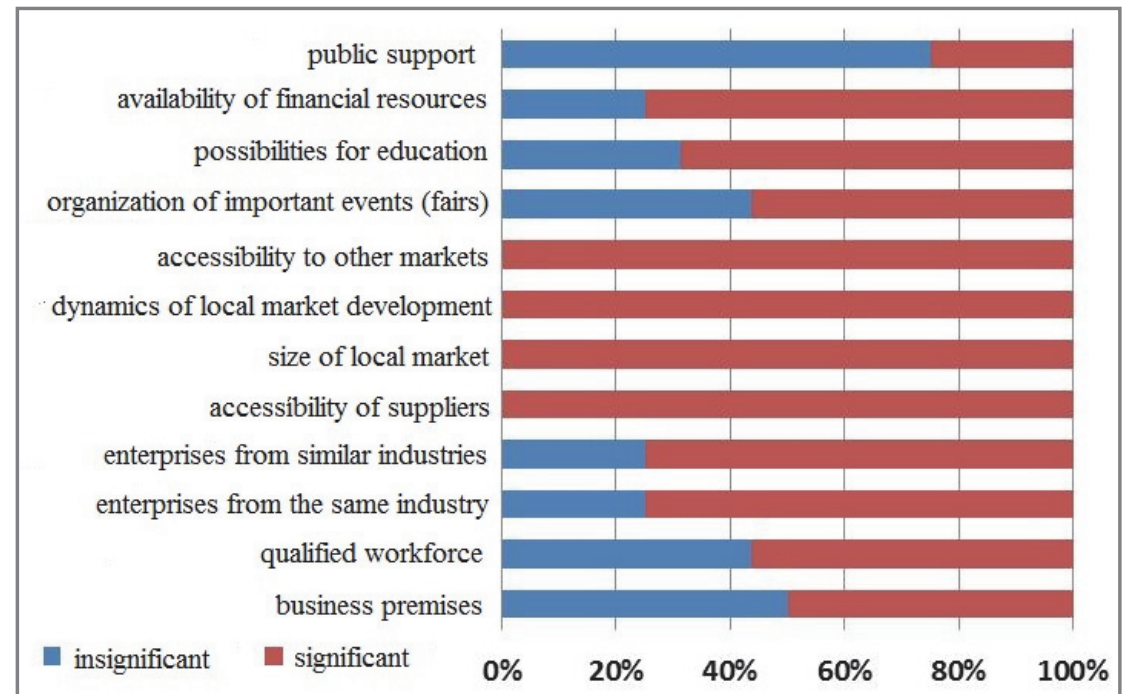

Figure 7 Evaluation of importance of local factors for running business in garden architecture

Source: own processing

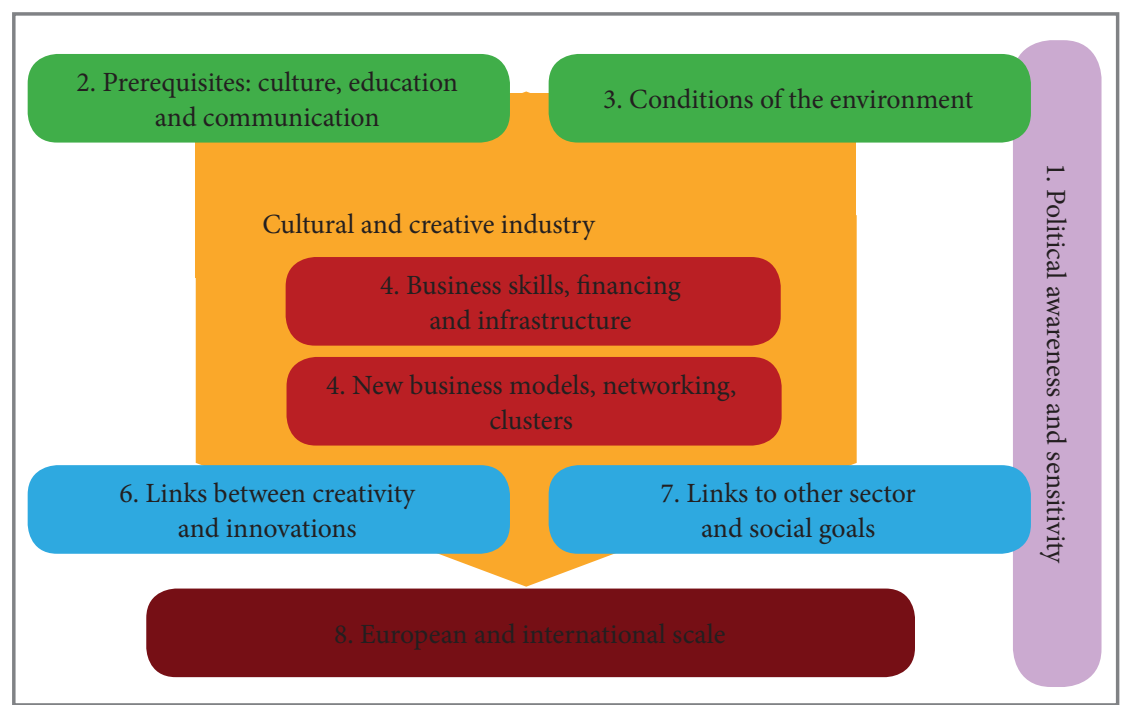

Figure 8 Basic relations of creative industry development with a potential to achieve international importance Source: FR OMC, 2010

Garden architecture is a sector with an ability to influence landscaping significantly, and thus indirectly affect the potential of land use not only in built-up areas. It can also utilize land in agriculture as well as other important sectors by changing and creating new fields in an area. Among those important sectors one should enlist tourism, enhancement of cultural potential in municipalities, improvement of free-time activities potential, thus improving the quality of life. Opposite to creative production of sculptors, painters and other artistic craftsmen, garden architecture enters the lives of people through works of the other hand, this very fragmentation makes it possible to swiftly react (either positively or negatively) to any change in the environment of its operation. Investments into the sector are the investments into sustainable development as it deals with an inexhaustible source and creates high added value. That is why it is necessary to enlist the support of creative industry into the priorities of the economic policy of the Slovak Republic (2011). To achieve further growth of creative economic performance of sectors, as well as increasing employment, it is necessary to create favorable (not only) business climate. Experience from abroad shows that significant positive changes can also be achieved by implementing special support mechanisms should be tailored to the needs of individual sectors (Balog et al., 2014).

According to the report of the EU working group on maximizing the potential of Cultural and Creative Industries in particular that of SMEs under the Directorate-General for Education and Culture, the favourable conditions for the development of creative industry must be generated in certain major lines, as presented in the diagram (Figure 8).

Within a regional policy, the position of garden architecture is also characterized by synergic links between the world of culture in a region and garden architecture production. These links are able to establish multiplication activities enhancing region's competitiveness and entrepreneurial climate in case they use the potential of social function agents in a region (Figure 9). Garden architecture may become a great contribution to agriculture; besides the optimization of land use by means of new projects, it can also affect employment in the sector. Some land adaptations are demanding in terms of manual labour, but they also need new technologies to be applied (water incorporated in a premises, fences with multiple functions decorative, with waterfalls, cropsgrowing, and arbores), that is why garden architecture is significant with respect to its impact on job creation and support of artistic crafts. 


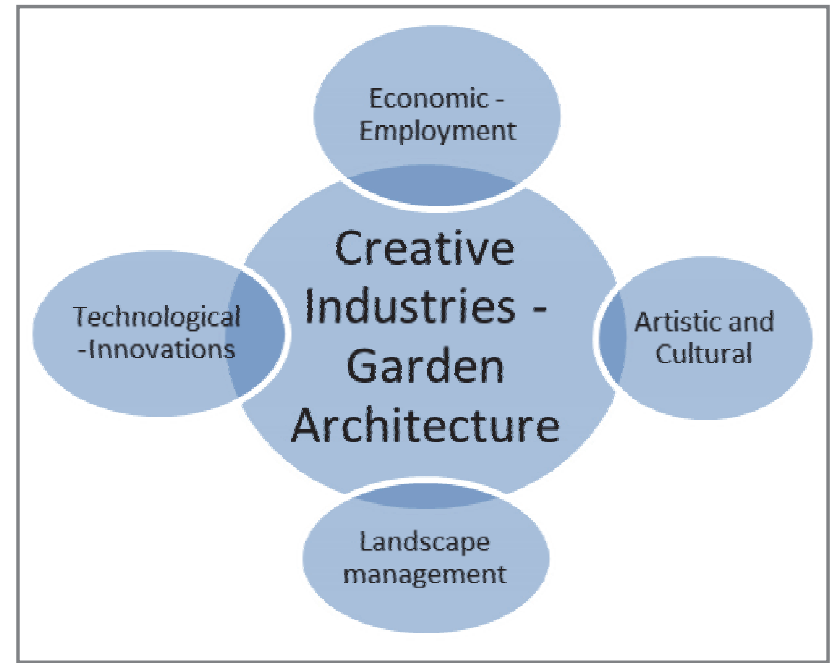

Figure 9 Relations of creative production within garden architecture in the region Source: own processing

Regional development focused on agriculture (with garden architecture as its part) is not understood only as an extensive economic development on the quantitative level, but also as a qualitative enhancement of economic structure and quality of life. Above all, it should improve the position of endangered social groups with no possibility to achieve at least an average level of income in case they decide to live in a region with a high share of agriculture. It should also adjust to socio-economic, natural and cultural features of a region. Contribution of garden architects lies in the fact that they become important agents of the area management policy, able to directly affect the development of business environment competitiveness in an area. Thus, they directly or indirectly influence the creation of workplaces and have the possibility to replace agricultural production in a region.

\section{Conclusion}

The specific nature of creative industry influences regional development and entrepreneurial conditions in a region. At the regional level has a specific strategy for the creative industries only region of Kosice in Slovakia (KSK, 2007). The strategy is based on five pillars: infrastructure; information system; human resource development and employment; marketing and promotion; networking and cooperation. Development of the creative economy is a challenge actors of regional policy in the new programming period of the EU.

Though the questioned garden architects do not emphasize the direct, supportive effect of national level decision-making as well as local and regional level regulations on their operations, the detailed analysis of their businesses shows that they pose barriers to their development, caused by e.g. social contributions, tax policy, position of the industry, non-existing support mechanisms. It means that regional and local authorities should be motivated to put emphasis on the necessary synergy in their decision-making and to encourage the development of business based on creative production.

\section{Acknowledgments}

The paper was written under the research project APVV0101-10 Creative Economy - National and Regional Conditions and Stimuli.

\section{References}

BALOG, M. - REHÁK, Š. - ŠIPIKAL, M. - SZITÁSIOVÁ, V. - HLINKA, M. - GAVOROVÁ, S. - PEŠOUT, I. 2014. Možnosti rozvoja kreatívneho priemyslu na Slovensku, Slovenská inovačná a energetická agentúra Bratislava 2014. on-line verzia. URL: https://www.google.sk/\#q=ISBN+978-80-88823-56-8. ISBN 978-80-88823-56-8

FLORIDA, R. 2002. The Rise of the Creative Class: And How It's Transforming Work, Leisure and Everyday Life, 2002, URL: http://www.creativeclass.com/richard_florida/books/ the_rise_of_the_creative_class.

FLORIDA, R. 2002. Entrepreneurship, Creativity, and Regional Development, 2002. on-line [cit. 2012-03-04] URL: http:// www.creativeclass.com/rfcgdb/articles/Entrepreneurship_ Creativity_and_Regional_Development.pdf

FINAL REPORT of OMC - Expert Working Group on maximising the potential of Cultural and Creative Industries, 2010. [on-line], [cit. 2012-05-26] URL: http://ec.europa.eu/culture/documents/ eu_omc_wg_cci_final_report_june_2010.

KOL: Východiská koncepcie na podporu kultúrneho a kreatívneho priemyslu v Slovenskej republike. Vláda SR. 14. 11. 2011

KÖNIG, H. J. - PODHORA, A. - HELMING, K. - ZHEN, L. - WANG, C. - WÜBBEKE, J. - BAUMEISTER, T. - DU, B. - YAN, H. 2014. Confronting international research topics with stakeholders on multifunctional land use: the case of Inner Mongolia, China. iForest (early view): e1-e11 [online 2014-05-19] URL: http:// www.sisef.it/iforest/contents/?id=ifor1172-007

KOŠICKÝ SAMOSPRÁVNY KRAJ (KSK 2007): Program hospodárskeho a sociálneho rozvoja KSK na roky 2007 - 2013. [Cit. 2013-04-27]. URL: <http://web.vucke.sk/files/dokumenty/ pub/regionalny_rozvoj/phsr/kap14.pdf>.

MARKUSEN, A. et al. 2008. Defining the Creative Economy: Industry and Occupational Approaches. Economic Development Quarterly, 2008, p. 24-45.

MILOTOVÁ, B. 2012. Creative industries localisation in Nitra selfgoverning region. In: Geografické informácie, vol. 16, 2012, no. 2, p. 50-60. ISSN 1337-9453.

UNCTAD Creative Economy report 2008 [online]. The United Nations, 2008 [cit. 2013-03-15].357 p. (PDF). ISBN 978-0-98166190-2. URL: http://unctad.org/en/docs/ditc20082cer_en.pdf.

\section{Contact address:}

doc. Ing. Viera Petrášová, CSc., Slovak University of Agriculture in Nitra, Faculty of European Studies and Regional Development, Department of Regional and Rural Development, phone 00421/37/641 45 66, e-mail: viera. petrasova@uniag.sk 